\title{
The Effect of Using Sentence of Question in the Beginning of Mathematics lesson in Primary School
}

\author{
Zulkarnain $^{1}$ \\ ${ }^{1}$ Faculty of Education, University of Riau, Pekanbaru, Indonesia \\ Correspondence: Zulkarnain, Faculty of Education, University of Riau, Pekanbaru, Indonesia. E-mail: \\ stoper65@yahoo.com
}

Received: August 1, 2013 Accepted: August 16, 2013 Online Published: August 30, 2013

doi:10.5539/ass.v9n12p195 URL: http://dx.doi.org/10.5539/ass.v9n12p195

\begin{abstract}
Developing students' ability in solving sentence questions is one of the important goals of mathematics learning at school, since sentence questions are able to increase the problem solving capability. However, mathematics is one of the subjects, less favoured by the students. Students' have poor mastery of mathematics other than difficulty in solving sentence questions. This has encouraged the execution of related research concerning enhancement of students' ability in solving sentence questions. This study aimed to investigate the influence of the use of sentence questions in the beginning of the lesson on the ability of solving mathematical sentence questions among the students of standard five of Primary School under the ministry of education. The study also aimed to examine the impacts of the use of the sentence questions on these students' attitude towards learning mathematics. The design of this research was quasi-experimental. As for this study, the research design was The One Group Pretest-posttest Design which was included in the Quasi Experimental Design without Control Group, with the sample of 44 students of Class V. Data collection was carried out by recording the test scores and administering the questionnaires on the attitude towards learning mathematics. Research findings showed that there was an influence of the use of sentence questions in the beginning of the lesson on the ability of solving mathematical sentence questions among the students. The contribution of the use of sentence questions in the beginning of the lesson to the enhancement of students' ability in solving the mathematical sentence questions was as high as $67.17 \%$. The research also discovered the positive influences of the use of the sentence questions on the attitude of the students towards mathematics learning. Furthermore, this study had given teachers the choice of using one of strategies of learning mathematics which was able to increase students' learning outcomes and improve their attitudes towards mathematics.
\end{abstract}

Keywords: influence, sentence questions, learning, ability, solving, attitude

\section{Introduction}

Students' mathematics learning outcomes can be seen in the aspect of their ability in solving calculation questions (non-narrative questions) and sentence questions. Sentence questions are questions which are constructed in form of narrations and situations faced by the students in daily lives. Just as stated in the Education Unit Level Curriculum 2006, one of the objectives of mathematics learning at the elementary and secondary levels is to prepare students to be resilient in facing the changing situations in life and the developing world through the practice of taking actions based on logical thinking, analyticity, systematicity, creativity, criticality, neatness, honesty, efficiency, efficacy, and ability to cooperate. Therefore, students should be taught with the questions which are applicative to their everyday lives. These questions are known as the sentence questions.

The use of sentence questions is one of the formal and material initiatives in achieving mathematics learning objectives. According to Marpaung (2004) the goals of mathematics learning consist of two aspects. The first aspect is formal, which focuses on the learners' structured reasoning and the establishment of personal attitude. The second aspect is material, which centres upon the mastery of mathematics, the mathematical application and practice, and the skills. As for the objectives, the formal aspect stresses on the structured reasoning which is reflected in the working of solving the sentence questions, whereas the material aspect emphasizes more on the skills of solving or analyzing the problems that include the steps of using mathematics. This can be observed in the activity of solving sentence questions which are presented in forms of stories and daily situations. 
Developing students' ability in solving sentence questions is one of the primary objectives of mathematics learning at school, as sentence questions have the potential to increase students' ability in analyzing problems. The skills of analyzing problems are something that must be possessed by the students, which is in accordance with the statement in the Education Unit Level Curriculum 2006 that the development of the problem analyzing ability is a requirement in mathematics learning. Through the problem analyzing activity, it is hoped that the material comprehension of mathematics will be strengthened and students' creativity will be generated.

Learning process that can guide and train students to analyse problems has not reached the sufficient and satisfactory point. Various findings in the field indicate that there was a weakness in the implementation of mathematics learning as the learning did not manage to prepare the students to learn how to analyze problems. Some of the findings are that (1) the mathematics learning was limited to giving the students the tips to enable them to answer the test questions (Armanto, 2002). The questions given were in form of objective tests, where students tended learn mathematics by memorizing the question examples or learning the questions whose analysis and answer keys are already known. Previous research also discovered that (2) mathematics learning was separated from the everyday experience (I Gusti, 2002) and that (3) mathematics teachers conducted teaching using the conventional methods (Zulkardi, 2005).

Nur (2000) claimed that contextual learning focuses on context as the commencement of the lesson, which functions as the replacement of the abstract introduction of concept. In contextual learning the development of mathematical concepts and ideas begins from the real world. The real world does not only refer to the concrete and visible physical characteristics, but also includes the things that are imaginable in students' mind due the experience they have. This means that the contextual problems used in the beginning of mathematics lesson can encompass the problems which really exist in students' life or the ones that can be imagined as real problems by the students. In line with this, Suwarsono (2000) suggested that contextual approach in mathematics learning is very beneficial in explaining certain things to students, such as the relationship between mathematics and the real world, the use of mathematics in human life, and the concept that mathematics is a knowledge that originates from the real life situations.

One of the strategies of employing the contextual approach in mathematics learning is beginning the lesson with the use of sentence questions which are related to the learning materials to be discussed. The use of sentence questions aims to make students realize about the use of mathematics in their daily lives, so that students will be more interested in the lesson. Next, teacher together with the students will implement the steps of solving the sentence questions, which cover the activities of identifying the details that are recognized in the question, determining the things asked in the question, constructing the mathematical model, doing calculation, and determining the final answer according to the requirement of the question. In this method, teacher's task is to guide the students to follow the steps. In the step of generating the mathematical model and before the step of performing calculations, teacher will explain the concepts, principles, and operations needed to solve the problems given (Zulkarnain 2000). In conventional learning, the explanation of concepts is done by the teacher in the beginning of the lesson.

\section{Statement of the Problem}

From another angle, mathematics is one of the subjects which is less favoured by the students even since from their elementary level, their mastery of mathematics is also poor (Soedjadi 2001; Regional Office of the Ministry of National Education of Riau 2004). Just as stated by Supartono (2006), the reality that is still often encountered is that there are still many students who face difficulties in learning mathematics. Some of the reasons causing the problems include the failure in disclosing the connection between mathematics and real life, and the monotonic technique of delivering mathematics lesson especially in the introduction of concepts which start with the abstract concepts and lead to the concrete ones, causing inconvenience in students' learning. Rohani (2005) proposed that students learn mathematics without realizing about its usage. Similarly, Zulkardi (2007) affirmed that there is a big problem in mathematics education in Indonesia. The issue is regarding students' low ability in solving the problems that are associated with their daily lives. Moreover, based on the achievement results of the national final examination 2005, it was discovered that on the average, the mathematics value at the elementary education level was about 5.13. Additionally, from the five subthemes of the national final examination questions which contained sentence questions, the average value gained was 5.03.

Furthermore, from the writers' observation on the elementary school students, secondary school students, and in fact all of the students, it was found that in general, they were not able to solve sentence questions, whereas if the questions were presented in the non-narrative forms, they would manage to solve the problems given. In addition, the results of The Third International Mathematics and Science Study (TIMSS) 2003 test found that the 
mathematics mastery of the Indonesian students ranked number 38 among all of the 40 countries. One of the reasons was that the questions asked related a lot to everyday life problems (contextual). In addition, a research done by Zulkarnain (2007) on 38 elementary school teachers in Riau using three sentence questions discovered that $78 \%$ of the teachers were able to determine what was meant by the questions, $36 \%$ managed to determine the material concept to be used to solve the sentence questions, and only $11 \%$ of them could answer the sentence questions correctly.

Based on the explanation above, it can be inferred that students' inability and/or weakness in solving mathematical sentence question is due to the application of the less accurate evaluation and the absence of teacher's instruction regarding the techniques of solving the mathematical sentence questions. Consequently, if the students are not able to solve mathematical questions that are in the narrative form, they will face difficulties in learning the mathematical elements contained in other subjects namely Economy, Physics, and Chemistry.

Another current challenging issue regarding mathematics learning is the poor attitude of the majority of the students towards mathematics (Zulkarnain, 2004). This poor attitude is attributable to the teaching factor. Teacher seldom (in some cases never) explains on the use of mathematics in everyday life (Zulkarnain, 2000), causing the students to be less interested in mathematics learning which will result in the lack of attention given by the students during the lesson. As a result, a lot of students do not understand the mathematical concepts taught by teacher and thus failing to answer the mathematical questions administered. This will further cause the students to be afraid of learning mathematics. Furthermore, the factor of the unsuitability of students' ability level in mathematics with the content presented by the teacher is also one of the elements leading to students' poor attitude towards the subject. Teacher wishes to quickly cover the entire lesson materials provided in the mathematics syllabus, whereas students have not managed to understand them.

There are a lot of factors influencing students' low productivity in solving sentence question and their poor mathematics learning outcomes. One of the factors is the learning. According to Sugiman et al. (2009), the learning that places students as the individuals receiving the mathematics knowledge is not effective in training the problem analyzing capability. Mathematics teacher instructs using the conventional method (Zulkardi, 2005). In the conventional learning model, teacher's roles are usually very dominant, while students are normally passive. The teaching strategies applied to students tend to be limited to merely transferring knowledge. This strategy should be changed, where the tasks assigned must focus on the activities that can stimulate students' creativity that will aid in increasing students' performance.

The establishment of human resources who possess the mastery of fundamental skills requires the availability of school facilities and teacher's ability in conducting teaching strategies. Teacher is challenged to shift from the traditional and routine teaching to the instruction that is more active and innovative, so that the learning process will always conform to the current education development which suits the current requirements of human resources. Innovative learning is able to produce students that are more creative, independent, and able to develop their thinking in solving problems.

Teacher's quality in teaching still needs to be improved. Although the training programs have been organized to establish teacher's ability, yet teacher's expertise in managing the teaching and learning process has not yet produced the maximal contributions to the development of human resources. This applies especially to the school teachers with limited background knowledge and skills in teaching.

\section{Literature}

\subsection{The Characteristics of Contextual Mathematics Learning}

As stated by Jaiman (2004), contextual learning centers upon the context as the commencement of the lesson, which acts as the replacement of the abstract introduction of concept. In the contextual or realistic mathematics learning, the process of developing the mathematical concepts and ideas originates from the real world. Normally, the real world not only refers to the concrete and visible physical characteristics, but also includes the things that are imaginable in students' mind based on the experience they have. This means that the contextual problems used during the early learning of mathematics can encompass the problems which are actual to students (really exist in students' life) or the ones that can be imagined as real problems by them. In simpler words, it is important for us to see the connection between mathematics and the real world, the use of mathematics in human life, and the concept that mathematics is a knowledge associated with the real life situations.

The mission of the contextual or realistic mathematics learning at school should not be seen as something that should only be achieved or diverted to students. Mathematics learning should instead be viewed as an activity that is called the process of mathematization. There are two types of mathematization processes that should 
occur in mathematics learning, consisting of the horizontal mathematization process and vertical mathematization process. The horizontal mathematization process takes place when there emerges a mathematical method or tool or mathematical model generated by the students, based on their effort of analyzing mathematical problems which are related to students' real life or thinking, which is asked by the teacher in the beginning of the learning process. The vertical mathematization process is the process of organizing the repetition of the mathematical method or tool or mathematical model which has been discovered (mentioned or found) by the students during the process of infusing the horizontal mathematization process into the formal mathematics system. Suryanto (in Marpaung, 2003) claimed that the horizontal mathematization founded by Freudenthal is interpreted as the shift from the real world to the world of symbol, while the vertical mathematization process is the movement or process occurring in the world of symbol itself. When a mathematics learning conducted by directly discussing the abstract mathematical symbols without previously associating the meaning with the real world or the relevant thinking owned by the students, it indicates that the learning activity only comprises the abstract vertical mathematization process.

Marpaung (2003) identified the characteristics of the contextual learning as follows : 1) Making connections that produce meaning, 2) learning self-regulated knowledge , 3) doing meaningful activities, 4) collaborating, 5)thinking critically and creatively, 6) nurturing every individual, 7) achieving high standards, 8) using authentic assessment. Therefore, the contextual learning, specifically in the field of mathematics studies, 1) requires students to be active in processing the information in order to obtain knowledge, 2) guides students to gradually see the significance of mathematics in the aspect of its connection with the their needs in analyzing problems in future, as mathematics is always related to contextual problems, 3) encourages students to interact with each other with the principle that learning together is more effective than learning with only individual competition, and 4) necessitates teacher's guidance in helping students to gain the expected knowledge. In contextual learning method, the time of learning is controlled by the students, not the teacher. The learning methods used are also varied and learning does not necessarily have to take place in the classroom. Apart from that, teacher does not really teach, instead, his/her roles rather focus on giving students the opportunities for developing their knowledge using their own strategies.

\subsection{Mathematical Sentence Question}

Questions that are used to test the students' ability in the field of mathematics study can be in form of sentence questions and non-narrative questions/calculation questions (Zulkarnain, 2011). Sentence question is the result of the modification of calculation questions that are related to the reality in students' environment.

One of the ways to help students deal with sentence question and generate the analyzing ability is by undertaking the following steps: a) Reading the question carefully to understand the meaning of each word b) Separating and saying what is known c) Constructing a mathematical model based on the question d) solving the model according to the mathematical rules until answer is produced from the model e) Returning the model's answer to the original question's answer (Zulkarnain, 2011). The process of solving sentence question above is described in the following diagram.

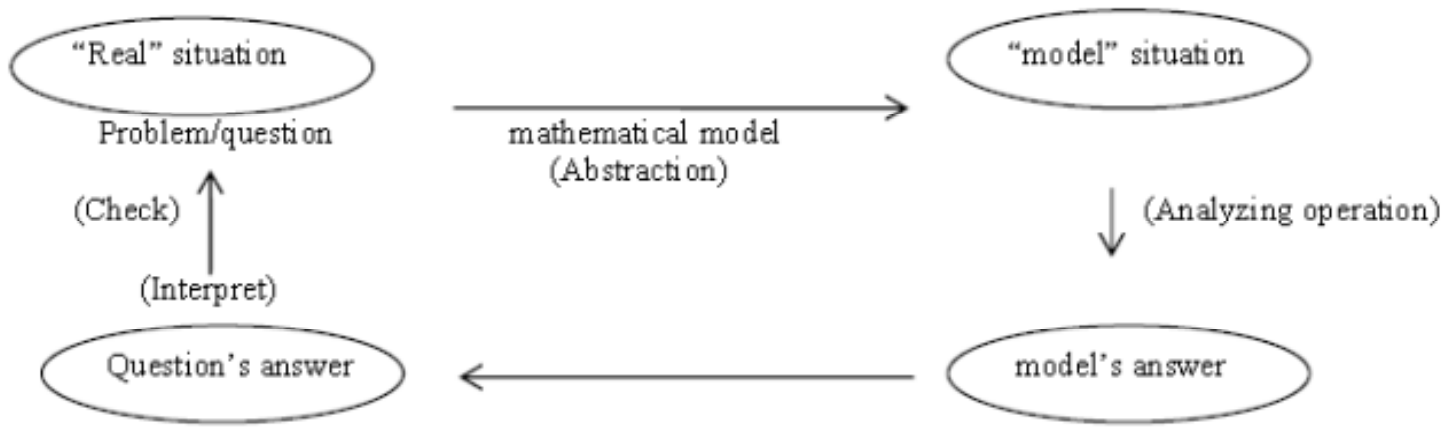

Figure 1. Procedures of solving sentence question

To be able to analyze the problem in real situation mathematically, the problem must first be modelled. The act of constructing a model requires the activity of abstraction. Through the abstraction activity, problem is manipulated until a mathematical model is created.

Based on the above diagram, it can be concluded that the steps that are required to solve the sentence questions in the study encompass a) Determining what is known b) determining what is asked c) Constructing a sketch or 
mathematical model d) Performing calculations and e) Deciding the final answer according to what is required by the question.

\subsection{Mathematics Learning Initiated with the Use of Sentence Question}

The lesson starts with the use of a sentence question that is associated with the learning materials to be discussed. The use of the sentence question aims to make students realize the use of mathematics in daily lives, so that students will be more interested in and attracted to the lesson. After that, the teacher together with the students will execute the steps of solving the sentence questions, which consist of the activities of identifying the details that are recognized in the question, determining the things asked in the question, constructing the mathematical model, doing calculation, and determining the final answer according to the requirement of the question. In this method, teacher's task is to guide the students to follow the steps. At the step of executing the mathematical model and before performing calculations, teacher will explain on the concept, principle, and operation needed to solve the problems given (Zulkarnain 2000). In conventional learning, the explanations of concepts are provided by the teacher in the beginning of the lesson.

According to Zulkarnain (2000) this kind of learning gives several advantages, which are 1) Motivates students in learning. Since the development of the mathematical concepts and ideas originate from the real world, students will be motivated to know the significance of the materials to be learnt. 2) Saves time. Usually, the learning of sentence question is done at the final part of the learning material. By introducing the sentence question in the beginning of the lesson, students will no longer need extra minutes to learn the sentence question. 3) In general, mathematical materials at school can be created in form of stories. The use of sentence question in the beginning of the lessons will get students to be used to the patterns of the question. This way, students will no longer be afraid of being asked with sentence questions.

\subsection{Students'Attitude towards Mathematics}

Attitude is something that is learnt and determines how an individual reacts towards a situation as well as what is searched by the individual in life. Attitude is also the tendency to act on certain objects. Attitude is not an obvious action, unless it is a closed attitude. Allport et al. (2005) defined attitude as the state of mind which is formed through experiences and influences the individual's reactions towards a situation in which he/she is in. Attitude is a phenomenon in students with the affective dimension in terms of the tendency to react or respond in a relatively consistent manner towards something positively or negatively (Syah 2004). Students' positive attitude towards mathematics learning is a good sign for the students' learning process. Conversely, students' negative attitude towards mathematics learning especially accompanied with the resentment towards the teacher will cause problems and difficulties in the students' learning. To avoid the possibility of the emergence of students' negative attitude, teacher is recommended to first show his/her positive attitudes towards himself/herself and the materials taught. Hudson (2006) stated that negative personality and perception of mathematics are some of the factors leading to the difficulty in learning the subject.

One of the factors which influences students' attitude towards mathematics is the teacher, which refers to the aspect of teacher's good teaching method. This can determine students' attitude towards his/her roles in the classroom. Therefore, teacher's teaching strategy which largely involves students to be active and creates convenient situations will determine students' positive and negative attitude, and thus determine their ability in learning. If the teacher manages to motivate students to get involved in the learning activities, he/she will be able to stimulate the students' positive attitude in interacting and dealing with mathematics learning. There are a few things that associate with attitudes, which include: (1) the relationship between behaviour and attitude, and (2) knowledge concerning the components of attitude.

A research by Darhim (2004) discovered that there was a positive influence produced by the contextual teaching and learning on students' attitude. In line with this, Saragih (2009) also found that the enhancement of students' positive attitude towards mathematics can be achieved through the learning using the contextual approach. Similarly, Mulyati (2009) in her research reported that there was a significant difference in the attitudes towards mathematics between the students who participated in contextual learning and the ones who enrolled in the conventional learning. Contextual approach gives better influence on students' attitude towards mathematics compared to the conventional approach.

\section{Purpose of the Research}

This study aimed to investigate the influence of the use of sentence question in the beginning of the lesson on the ability of solving mathematical sentence question of the standard 5 students in Pekanbaru Riau, Indonesian during the 2012/2013 school session. This research was also carried out to examine the influence of the use of 
sentence question in the beginning of the lesson on students' attitude towards mathematics.

\section{Methodology}

The design of this research is quasi-experimental. According to Sugiyono (2010), the quasi- experimental approach is used to find out the influence of certain actions on other actions in the controlled situations. As for this research, the design used was the single Group Pretest/posttest Design (Jackson, 2003) which is included in the Quasi-Experimental Design Without Control Group category. The design of this study can be described as follows:

$\begin{array}{lll}\mathrm{O} 1 & \mathrm{X} & \mathrm{O} 2\end{array}$

The design involved an experimental group which received the treatment of the use of sentence question in the beginning of the lesson $(\mathrm{X}) . \mathrm{O}_{1}$ is the results of the pre-test administered to the sample regarding the learning materials which have been learnt in form of sentence question and the questionnaires concerning students' attitude towards mathematics. $\mathrm{O}_{2}$ is the result of the post test administered to the sample regarding the learning materials after the sentence question treatment and the use of questionnaires regarding students' attitude towards mathematics had been carried out.

In the aspect of the implementation of learning, the "use of sentence question in the beginning of the lesson" was done by the teachers of the Pekanbaru Public Primary School. These teachers were first given trainings until they are skilful in executing the lessons. This training was organized in the early October 2012. The execution of the study was started on 8th October 2012 with 10 meetings, two post tests, one pre test, and the use of the questionnaires on attitude. The research ended on 7th November 2012. The sample of this study consisted of all of the 44 students of Class V of Pekanbaru Public Primary School comprising 25 students from Class V-A and 19 students from Class V-B. The instruments employed in this research encompassed the learning devices and data collection instruments. Data collection was carried out by recording the results of the mathematics learning outcomes test. The data obtained via the questionnaires on students' attitude towards mathematics was analyzed using the inferential statistics. The data of the learning outcomes was analyzed using the T-Test, whereas the data gained from the questionnaires was analyzed using the Sign Test with $\alpha=0.05$.

\section{Findings and Discussions}

The analysis of students' learning outcome data was executed by analyzing the performance in the pre test and post test. The majority of the post test data was collected from the two daily repetition papers. The data of students' learning outcomes was analyzed to test the observational hypothesis. The steps of the tests include the homogeneity of variance test, the difference of means test (hypothesis test), and the influence test to find out the influence level of the treatment. The homogeneity of variance test showed that the variance of the pre-test and post-test data were not homogeneous. This has prompted the researcher to carry out the T-Test to further examine the difference of means. The overall analysis resulted in the rejection of the hypothesis $\mathrm{H}_{0}$, and the acceptation of the hypothesis $\mathrm{H}_{1}$. This implies that the ability of solving the mathematical sentence question during the post test was better than the ability of solving the mathematical sentence question during the pre-test.

This means that the ability of solving mathematical sentence question was improved after being treated with the use of sentence in the beginning of the lesson. The experiment was carried out to know the influence level of the treatment. After the execution of the experiment, it was found that the value of $r^{2}=0.6717$ with the influence coefficient or $\mathrm{Kp}=67.17 \%$. In other words, it can be concluded that the influence of the use of sentence question in the beginning of the lesson on the improvement of the ability in solving mathematical sentence question was as much as $67.17 \%$. The research findings support the findings of several previous studies, namely the research done by Jatnika (2007) who discovered that students' activity through the contextual approach was able to increase the outcomes of students' mathematics learning. Darhim (2004), Harliyani (2005), and Mulyati (2009) also found that there was a significant difference in the learning outcomes of the students who participated in the contextual learning and the conventional learning. The contextual learning gave better influence on the outcomes of students' mathematics learning compared to the conventional learning.

Data from the survey on students' attitude towards mathematics was analyzed using the Sign Test. The results of the processed data indicated that the value of $p=0.0031$, and that the valued of $p=0.0031<\alpha=0.05$. Based on this, it can be concluded that students' attitude towards mathematics was better after the use of the treatment, which was the act of beginning the lesson with the use of sentence question. These findings are in line with a statement from Syah (2004), stating that students' positive attitude towards mathematics learning is a good sign for the students' learning process. Contrarily, students' negative attitude towards mathematics learning especially accompanied with the resentment towards the teacher will cause problems and difficulties in the students' 
learning. To avoid the possibility of the emergence of students' negative attitude, teacher is recommended to first show his/her positive attitudes towards himself/herself and the materials taught. The findings of the study was also parallel with a research done by Darhim (2004), which discovered that there was a positive influence of contextual learning on students' attitude; and a research undertaken by Saragih (2009) which observed the improvement in students' positive attitude towards mathematics as a result of the participation in the learning that employs contextual approaches.

Although the students have experienced a major influence of the application of the use of the sentence question in the beginning of the lesson on their ability in solving mathematical sentence question, yet based on the results of the review of students' daily repetition paper, there were still several errors found. The students' daily repetition papers which contained questions on the plane figures consisted of 4 questions altogether. Question number one associated with the item on the area of parallelogram. Question number two asked about the measurement of the area of rhombus, question number three focused on the measurement of the area of trapezium, and question number four was related to the measurement of the area of kite. The review results of the daily repetition papers can be observed in the following table.

Table 1. The frequency of students' ability in solving the sentence questions on the items on the area of the plane figures

\begin{tabular}{|c|c|c|c|c|c|c|c|c|}
\hline \multirow[t]{2}{*}{$\begin{array}{l}\text { Steps of solving the } \\
\text { sentence questions }\end{array}$} & \multicolumn{8}{|c|}{$\begin{array}{l}\text { Question Number } \\
1\end{array}$} \\
\hline & $\mathrm{F}$ & $\%$ & $\mathrm{~F}$ & $\%$ & $\mathrm{~F}$ & $\%$ & $\mathrm{~F}$ & $\%$ \\
\hline $\begin{array}{l}\text { Determining the discovered } \\
\text { details }\end{array}$ & 44 & 100 & 37 & 84.09 & 42 & 95.45 & 21 & 47.73 \\
\hline $\begin{array}{l}\text { Determining the asked } \\
\text { items }\end{array}$ & 44 & 100 & 40 & 90.91 & 42 & 95.45 & 33 & 75 \\
\hline $\begin{array}{l}\text { Constructing the } \\
\text { mathematical model }\end{array}$ & 30 & 68.18 & 25 & 56.82 & 25 & 56.82 & 28 & 63.64 \\
\hline Performing the Operation & 25 & 56.82 & 19 & 43.18 & 23 & 52.27 & 18 & 40.91 \\
\hline $\begin{array}{l}\text { Determining the final } \\
\text { answer }\end{array}$ & 19 & 43.18 & 18 & 40.91 & 21 & 47.73 & 18 & 40.91 \\
\hline
\end{tabular}

F : Frequency

Table 1 presented the students' ability in solving the sentence questions on the measurement of the area of the plane figures. For the first question, students still made some errors in the construction of the mathematical model. This was due to students' errors in stating down the formula for the area of parallelogram. In addition, in the aspect of students' errors in performing the operation, other than the errors made in the construction of the mathematical model, there were also students who made errors in the multiplication of the integers. In the final step, the errors made by the students were affected by the previous errors and the errors in calculating the unit area.

For the second question, there were still students who committed errors in determining the discovered contents and the details that were asked. In this aspect, students were not complete in determining the contents that are discovered in the question, and did not perform the items asked. In the step of constructing the mathematical model, the errors made include the failure in understanding the question and the lack of knowledge about the shape of the plane figure asked, causing the students to make errors in constructing the formula for the area of rhombus. Moreover, in the step of solving the operational problem, students' errors were the results of the previous errors and the errors in interpreting the statement " the measurement of the second diagonal was $12 \mathrm{~cm}$ longer than the first diagonal", causing students to make errors in performing the operations. In determining the final answer, students' errors were influenced by the previous errors as well as the errors in returning to the original question.

For the third question, there were only two students who made errors in determining the contents that were discovered and the details that were asked. In this matter, the students were incomplete in determining the 
contents that are discovered in the question, and did not perform the items asked. In the step of constructing the mathematical model, the errors made were the failure in understanding the question and the lack of knowledge about the shape of the plane figure asked, causing the students to make errors in constructing the formula for the area of trapezium. Other than that, students also make errors in generating the formula for the area of trapezium due to the forgetfulness of dividing the formulas by two. In the step of performing the operations, the errors made were the affected by the previous errors and the errors in dividing the integers. In determining the final answer, students' errors were the results of the errors in the previous steps.

For the fourth question, students were not complete in determining the details discovered in the question. Students also did not work out the items asked. In the step of generating the mathematical model, the errors committed by the students were the inability in understanding the question and the errors in constructing the formula for the area of kite. Furthermore, in the step of performing the operations, students' errors were influenced by the errors in the previous steps and the errors in interpreting the statement "to cover the kites, it must be given a centimetre length at each of its ends", causing the students to commit errors in doing out the operations. In determining the final product, the errors done by the students were the results of the errors in the previous steps.

The following are the results of the review of the daily repetition papers which contained the materials on the volume of solids comprising three questions. The first question associated with the item on the volume of triangular prism, the second question asked about the volume of pyramid, and the third question was related to the volume of beam. The results of the review of the daily repetition papers can be seen in the following table.

Table 2. The frequency of students' ability in solving the sentence questions on the items on the volume of solids

\begin{tabular}{|c|c|c|c|c|c|c|}
\hline \multirow{3}{*}{ Steps of solving the sentence questions } & \multicolumn{6}{|c|}{ Question Number } \\
\hline & \multicolumn{2}{|l|}{1} & \multicolumn{2}{|l|}{2} & \multicolumn{2}{|l|}{3} \\
\hline & $\mathrm{F}$ & $\%$ & $\mathrm{~F}$ & $\%$ & $\mathrm{~F}$ & $\%$ \\
\hline Determining the discovered details & 29 & 65.91 & 38 & 86.36 & 34 & 77.27 \\
\hline Determining the asked items & 44 & 100 & 44 & 100 & 35 & 79.55 \\
\hline Constructing the mathematical model & 19 & 43.18 & 15 & 34.09 & 29 & 65.91 \\
\hline Performing the Operation & 18 & 40.91 & 12 & 27.27 & 5 & 11.36 \\
\hline Determining the final answer & 18 & 40.91 & 9 & 20.45 & 5 & 11.36 \\
\hline
\end{tabular}

F: Frequency

Table 2 describes the students' ability in solving the sentence questions which were related to the learning materials on the volume of solids. For question number one, the errors done by the students during the process of determining the discovered details were caused by the students' inability in recognizing the picture of the solid contained in the question. In the step of constructing the mathematical model, the errors done were the effects of students' failure in recognizing the picture in the question, leading to their inability in determining the formula for the volume of the solid presented in the picture. Another error committed by the students was their failure in determining the formula for the base of the triangle contained in the picture. In the step of performing the operation and determining the final answer, students made errors in terms of multiplication.

For question number two, students' errors in determining the discovered details in the question were caused by students' incompleteness in determining all of the elements contained in the question. In the construction of the mathematical model, students' errors occurred due to their failure in generating the formula for the volume of pyramid, which was written as $\mathrm{v}=\frac{s x s x t}{2}$ instead of $\mathrm{v}=\frac{s x s x t}{3}$, causing students to be erroneous in forming the formula for the calculation of the height of the pyramid. Another error committed was the students' inability to change the formula $\mathrm{v}=\frac{s x s x t}{3}$ to $\mathrm{t}=\frac{3 v}{s \times s}$. Instead, students had formed the formula wrongly by writing it as $\mathrm{t}$ 
$=\frac{v}{s \times s}$. In the step of performing the operations, students' errors was calculating $50,000=\frac{50 \times 50 \times t}{3}$ as $\mathrm{t}=$ $\frac{50,000}{50 \times 50}$, instead of $\mathrm{t}=\frac{3 \times 50,000}{50 \times 50}$.

For the third question, errors were done a lot in the step of performing the operations. The main error was the error in analyzing the question, where students failed to determine that the base of the square beam was the same as its volume measurement, which was $125,000 \mathrm{~cm} 3$. In this aspect, students were unable to see the relationship between the measurement of the base of the square beam and the measurement of the cube whose volume was known. Students were also unable to determine the value of $\sqrt[3]{125,000}$, due to their weakness in the operation of multiplication.

\section{Implication}

This study found that there was an influence of the use of the sentence question in the beginning of the lesson on the ability of the standard 5 students in solving the mathematical sentence questions. The findings suggest teachers that the use of sentence questions can be made as one of the strategies to be used to enhance students' competence in solving problems. Teachers need to prepare themselves to organize and form sentence questions before the process of teaching and learning are implemented, and to adapt the sentence questions with the learning objectives to be achieved.

\section{Conclusion}

Based on the findings of this study and the arguments presented in the earlier chapters, it can be concluded that:

1) There was an influence of the use of the sentence question in the beginning of the lesson on the ability of solving the mathematical sentence questions among the students of Class V of Pekanbaru Public Primary School. The influence of the application of the use of sentence question in the beginning of the lesson on the improvement of the ability in solving mathematical sentence question was as big as $67.17 \%$.

2) There was an influence of the use of the sentence question in the beginning of the lesson on the attitude towards mathematics among the students. This influence which was observed in the research findings was positive.

\section{Recommendation}

Based on the experience obtained throughout the execution of the study, the research has provided the following suggestions:

Lesson should be started with the use of sentence questions as the alternative of an innovative learning which is able to generate better ability to solve the mathematical sentence questions, leading to the enhancement in the outcomes of students' mathematics learning. In addition, due to the restriction of funds, this study was only executed in one school. Therefore, it is recommended for other researchers who would like to develop this research to extend the place of research to a bigger location, namely the city, region, or province if possible.

\section{References}

Allport, G. W., Blanshard, B., Morgan, A., Sullivan, R., Taylor, H., \& Klein, J. (2005). The Goals of Higher Education. California: Experienced Books.

Armanto, D. (2002). Teaching Multiplication and Division Realistically in Indonesian Primary School: A Prototype of Local Instructional Theory. Dissertation. Enschede: Print Partners Ipskamp.

BSNP. (2006). Kurikulum Tingkat Satuan Pendidikan. BSNP: Jakarta.

Darhim. (2004). Pengaruh Pembelajaran Kontekstual Terhadap Hasil Belajar dan Sikap Murid SD Kelas Awal Dalam Matematik. Disertasi, tidak diterbitkan. Bandung: PPS UPI.

Dinas Pendidikan Provinsi Riau. (2004). Data dan Informasi Pendidikan Provinsi Riau tahun 2003. Pekanbaru.

Harliyani, D. (2005). Pengaruh Pendekatakan kontekstual dalam Pembelajaran Matematik terhadap Motivasi dan Hasil Belajar MatematikMurid di Kelas V SD Blambangan Bojonegoro. Laporan Kajian: FMIPA UNESA.

Hudson, K. (2006). An Analysis of Goals 2000: Redefining American Education. Massachusetts: Noram International Partners.

Jackson, S. L. (2003). Research Methodes and Statistics. Singapore: Thomson Learning. 
Jaiman, J. (2004). Pengajaran Matematik Kontekstual. (Makalah) disampaikan dalam seminar Nasional Pendidikan Matematik di FKIP UNRI, 18 Februari 2004.

Jatnika, T. (2007). Pembelajaran Matematik Melalui Pendekatan Kontekstual di Kelas IV SDN Cipetir Jawa Barat. Retrieved from digilib.upi.edu/pasca/available/etd-1222106-111445/

Marpaung, Y. (2003). Perubahan Paradigma Pembelajaran Matematik di Sekolah. (Makalah) disampaikan dalam Seminar Nasional Pendidikan Matematik, di Yogyakarta, 27-28 Maret 2003.

Marpaung, Y. (2004). Mengejar Ketertinggalan Kita dalam Pendidikan Matematik. Unesapress: Surabaya.

Mulyati, S. (2009). Pengaruh Pendekatan Kontekstual Dalam Proses Belajar Mengajar Matematik Terhadap Sikap, Motivasi, dan Hasil Belajar Murid Kelas VII SMP Labor UM. Retrieved from Karya-ilmiah.um.ac.id/index.php/disertasi/article/view/985

Nur, M. (2000). Realistic Mathematics Education. Makalah dalam seminar Tentang Contextual Learning Dalam Pendidikan Matematik di Unesa Surabaya.

Rohani, A. (2005). Pengelolaan Pengajaran. Edisi Revisi. Rineka Cipta: Jakarta.

Saragih, S. (2009). Menumbuh kembangkan Berpikir Logis dan Sikap Positif Terhadap Matematik Melalui Pendekatan Matematik Realistik. Proseding Konprensi Nasional Matematik. Medan: UNIMED.

Soedjadi, R. (2001). Nilai-Nilai dalam Pendidikan Matematik dan Upaya Pembinaan Pribadi Anak Didik. Unesa: Surabaya

Sugiyono. (2010). Metode Kajian Pendidikan Pendekatan Kuantitatif, Kualitatif, dan $R \&$ D. Alfabeta, Bandung.

Suharta, I. G. P. (2002). Matematik Realistik; Apa dan Bagaimana. Jurnal Pendidikan dan Kebudayaan Badan Kajian dan Pengembangan Departemen Pendidikan Nasional No. 38 tahun ke-8.

Supartono. (2006). Pengembangan Perangkat Pembelajaran Matematik Realistik untuk Materi lingkaran di kelas VIII SMP Negeri 1 Bubulan Bojonegoro. Mathedu; Vol 1 No. 2 Juli 2006. PPS UNESA: Surabaya.

Suwarsono, S. (2002). Teori-teori Perkembangan Kognitif Dalam Proses Pengajaran yang Relevan untuk Pengajaran Matematik. Makalah tidak dipublikasikan pada pelatihan Terintegrasi Berbasis Kompetensi untuk Guru Mata Pelajaran Matematik SMP tanggal 4 - 17 Februari 2001 di PPPG Matematik oleh Direktorat SMP Jakarta.

Syah, M. (2004). Psikologi Pendidikan. Bandung: PT. Remaja Rosdakarya.

Zulkardi. (2005). Peningkatan Mutu Pendidikan Matematik Melalui Pembelajaran. Retrieved from http://www.pikiran-rakyat.com

Zulkardi. (2007). Arti PISA, TIMSS, dan UN bagi Guru Matematik. Makalah Seminar Nasional Pendidikan Matematik. PPS FKIP UNSRI Palembang, 4 September 2007.

Zulkarnain. (2000). Pembelajaran Yang Dimulai Dengan Pemberian Soalan berayat Untuk Meningkatkan Hasil belajar MatematikMurid Kelas II SMAN 2 Pekanbaru. Laporan Kajian. Pekanbaru: Lemlit UNRI.

Zulkarnain. (2004). Kesalahan Yang dilakukan Murid SD Provinsi Riau Dalam Menyelesaikan Soalan berayat. Makalah: Disajikan Pada SEMIRATA BKS PTN Wilayah Barat di Unand Padang.

Zulkarnain. (2007). Identifikasi Kesalahan Guru-Guru SD di Privinsi Riau dalam Menyelesaikan Soalan berayat. Makalah: Disajikan Pada SEMIRATA BKS PTN Wilayah Barat di UIN Syarif Hidayatullah Jakarta.

Zulkarnain. (2011). Pengajaran dan Pembelajaran Matematik Melalui Soalan Berayat Berbentuk Kontekstual: Penyelidikan Tindakan di SDN 004 Rumbai Pekanbaru. (Tesis Doktoral) Fakulti Pendidikan UKM.

\section{Copyrights}

Copyright for this article is retained by the author(s), with first publication rights granted to the journal.

This is an open-access article distributed under the terms and conditions of the Creative Commons Attribution license (http://creativecommons.org/licenses/by/3.0/). 